\title{
Karaciğer sirozunda serum von Willebrand faktörü düzeyleri ile hepatik yetmezlik derecesi arasındaki ilişkinin değerlendirilmesi
}

\author{
Evaluation of the relationship between serum von Willebrand factor levels and hepatic deficiency \\ in patients with liver cirrhosis
}

\author{
(D) Süleyman GÜNAY', (D Mustafa YILDIRIM², (DZZehra Betül PAKÖZ , (DCem ÇEKIÇ ${ }^{1}$ \\ Katip Çelebi Üniversitesi Atatürk Eğitim ve Araştırma Hastanesi, ' Gastroenteroloji Kliniği, İzmir \\ Tepecik Eğitim ve Araştırma Hastanesi, ${ }^{2}$ iç Hastalıkları Kliniği, ${ }^{3}$ Gastroenteroloji Kliniği, İzmir
}

\begin{abstract}
Giriş ve Amaç: Karaciğer sirozu olan hastalarda, karaciğer yetmezliği derecesi ve prognozun ön görülmesinde günümüzde Child-Pugh ve MELD (model of end stage liver disease) skorları kullanılmaktadır. Asıl olarak hemostazın sağlanmasında rol oynayan von Willebrand faktörün, karaciğer hastalıklarında serum düzeyi artmaktadır. Bu çalışmada sirozlu hastalarda serum von Willebrand faktör düzeyleri ile Child-Pugh, MELD ve sodyum-MELD skorları karşılaştırılarak von Willebrand faktörünün prognostik değerinin belirlenmesi amaçlanmıştır. Gereç ve Yöntem: Çalışmaya karaciğer sirozu olan 41 hasta alındı. Çalışmada değerlendirilen skorlama sistemlerinin belirlenmesi amacıyla klinik ve laboratuvar parametreleri kaydedildi. Takiben serum von Willebrand faktör düzeyleri ile Child-Pugh, MELD ve sodyum-MELD skorları arasında korelasyon analizleri yapıldı. Serum von Willebrand faktörün prognostik değerinin belirlenmesi amacı ile ROC analizi yapıldı. Bulgular: Hasta grubunda yapılan analizde median serum von Willebrand faktör düzeyi 176 olarak bulundu. von Willebrand faktör düzeyleri ile Child-Pugh, MELD ve sodyum-MELD skorları arasında yapılan korelasyon analizinde; pozitif yönlü anlamlı bir korelasyon saptanmadı. Subgrup analizlerde; von Willebrand faktör ile serum bilirübin ve von Willebrand faktör düzeyleri arasında istatistiksel olarak anlamlı bir ilişki tespit edildi. Sonuç: Bu çalışmadan elde edilen veriler ışı̆ıında; serum von Willebrand faktör düzeylerinin, karaciğer sirozunun şiddetinin belirlenmesinde ve prognozun ön görülmesinde etkili bir belirteç olduğuna dair yeterli kanıta ulaşılamamıştır.
\end{abstract}

Anahtar kelimeler: Siroz, von Willebrant faktör, MELD skoru
Background and Aims: Child-Pugh and model of end-stage liver disease scores are used to predict the degree of liver failure and prognosis in patients with liver cirrhosis. The serum level of von Willebrand factor, which plays a role in hemostasis, increases in liver diseases. We aimed to compare the serum von Willebrand factor levels with Child-Pugh, MELD, and MELD-Na scores in patients with liver cirrhosis and to determine the prognostic value of von Willebrand factor. Materials and Methods: The study included 41 patients with liver cirrhosis. Clinical and laboratory parameters were recorded to determine the scoring systems evaluated in the study. Correlation analysis was performed between serum von Willebrand factor levels and Child-Pugh, MELD, and MELD-Na scores. Receiver operating characteristic curve analysis was performed to determine the prognostic value of serum von Willebrand factor. Results: The median serum von Willebrand factor level was found to be $176 \mathrm{IU} / \mathrm{dL}$ in the patient group. In the correlation analysis between von Willebrand factor levels and Child-Pugh, MELD, and MELD-Na scores, no significant positive correlation was found. There was a statistically significant association between the levels of von Willebrand factor and serum bilirubin and international normalized ratio in the subgroup analysis. Conclusion: In the light of the data obtained from this study, there is no enough evidence that serum von Willebrand factor levels are effective predictors of the severity of liver cirrhosis and prognosis.

Key words: Cirrhosis, von Willebrand Factor, MELD score

yüksek olduğunu göstermiş̧ir (2,3). Objektif skorlama sistemlerine olan intiyaç sebebi ile son yllarda sodyum $(\mathrm{Na})$ değerinin formüle eklenmesiyle elde edilen MELDNa skorlama sistemi geliştirilmiştir (4).

von Willebrand Faktör (vWF), megakaryositler ve aktive endotel hücrelerinde sentezlenen, trombositlerin alfa granüllerinde ve endotel hücrelerinin sitoplazmasında bulunan büyük multimerik bir glikoproteindir (5). VWF, trombositlerin endotele adezyonunda ve trombosit ag-

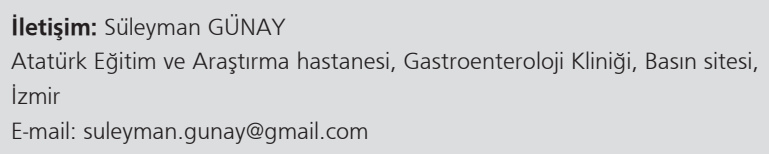

Siroz, karaciğer hastalıklarına bağlı mortalite ve morbiditenin en yaygın sebebidir. Sirotik hastalarda hastalığın şiddetini, prognozunu ve sağ kalımını belirlemede günümüzde Child-Pugh ve modifiye son dönem karaciğer hastalı̆ı (MELD - model of end stage liver disease) skorları kullanılmaktadır. Child-Pugh skorlama sisteminde subjektif kriterler olması nedeni ile özellikle transplantasyon hastalarında MELD skorlama sistemi daha sık kullanılmaktadır (1). Fakat çeşitli çalışmalar ve klinik gözlemler, düşük MELD skorlarına rağmen bazı hastalarda mortalitenin
Geliş Tarihi: 27.11.2018 • Kabul Tarihi: 18.04.2019 
regasyonunda rol oynamaktadır. Ayrıca faktör VIII için taşıyıcı bir protein rolü üstlenerek faktörün proteolizden korunmasında görev alır $(5,6)$. vWF'nin kronik karaciğer hastalıklarında düzeyinin arttığı bilinmektedir. Sirozda megakaryositler ve aktive endotel hücrelerinden artan salınımı ayrıca hepatik yetmezlik nedeni ile azalan ekskresyonu vWF'nin serum düzeylerinde artış ile sonuçlanır. Ayrıca akut faz reaktanı benzeri etkinliği ile asit enfeksiyonu gibi endotoksemik ortamlarda artan serum düzeyleri de VWF'nin artışının sebebi olarak gösterilmiştir (7).

Daha önceden yapılan çalışmalarda karaciğer sirozunda VWF düzeylerinin kontrol grubuna göre anlamlı olarak arttığı gösterilmiştir. Bu çalışmanın amacı, etiyolojiden bağımsız olarak karaciğer sirozu gelişmiş hastalarda vWFAg düzeyinin Child-Pugh, MELD ve MELD-Na skorları ile korelasyonunun araştırılmasıdır.

\section{GEREÇ ve YÖNTEM}

Bu çalışmaya Eylül 2015-Nisan 2016 tarihleri arasında kliniğimize başvuran, farklı evrelerdeki karaciğer sirozlu 41 hasta alınmıştır.

\section{Çalışma Dizaynı}

Yaş, cinsiyet, hastalık etiyolojisi gibi hastalara ait demografik veriler kaydedildi. Çalışmada karaciğer hastalığının şiddetini tanımlamak için kullanılan, Child Pugh, MELD ve MELD-Na skorlamalarının hesaplanabilmesi için gereken laboratuvar ve klinik parameterler belirlendi [asit varlığı, ensefalopati, sodyum, kreatinin, total bilirübin, albümin, uluslararası normalleştirilmiş oran (INR) ve trombosit]. Hepatik ensefalopati (yok, evre 1-2, evre 3-4) ve assit (yok, hafif, şiddetli) Child-Pugh skorlamasına göre sınıflandırıldı (1).

Hastalar Child-Pugh skoruna göre A (5-6), B (7-9) ve C (10-15) olarak sınıflandırıldı. MELD ve MELD-Na skoru 0-10, 11-20 ve 21-30 olmak üzere 3 gruba ayrilarak incelendi. Son olarak, vWF-Ag düzeyleri ile skorlamalar arasında korelasyon analizi yapıldı.

Biyokimyasal analizler için Olympus AO5800 otoanalizöründe enzimatik metod ile ölçülen veriler kullanılmıştır.

\section{Dışlama Kriterleri}

Gebelik, aktif enfeksiyon varlığı, antikoagülan ve antiagregan tedavi kullanımı olan hastalar ile kronik böbrek yetmezliği olan ve 18 yaşından küçük hastalar çalışmaya alınmadı.

\section{vWF-Ag Düzeylerinin Belirlenmesi}

vWF-Ag düzeyi çalışıması için, hastalardan alınan venöz kan örneği sitratlı biyokimya tüplerine alındı. Kan örnek- lerinden 1 saat içinde serum ayrılarak -80 derecede muhafaza edildi. vWF-Ag testi immünotürbiadimetrik ölçüm yöntemi kullanılarak STA Compact (Diagnostica Stago) cihazı ile çalışıldı ve sonuçlar absU birimi ile kaydedildi.

Çalışma için etik kurul onayı alınmış ve tüm hastalardan bilgilendirilmiş onam formu alınmıştır.

\section{İstatistiksel Analiz}

Tüm analizler SPSS17.0 programı kullanılarak gerçekleştirildi. Numerik değişkenlerin normal dağılıma uygunluğu Shapiro Wilk Testi ile değerlendirildi. Kategorik değişkenler frekans ve yüzde, numerik değişkenler ortalama ve standart sapma veya medyan ve minimum-maksimum değerleri ile tanımlandı. Numerik değişkenler arasındaki ilişkinin analizinde Spearman Korelasyon Analizinden yararlanıldı. İki kategorik değişken arasındaki ilişki Ki-kare Testi ile analiz edildi. İi bağımsız örnek medyan değerinin karşılaşıııılmasında Kruskal Wallis Testi kullanıldı. VWF değerinin prediktik özelliği ROC analizi ile test edildi. Çalışma \%95 güven düzeyinde gerçekleştirildi ( $p<0.05$ istatistiksel anlamlı kabul edildi).

\section{BULGULAR}

Çalışmaya, klinik, radyolojik ve endoskopik olarak tanı almış 41 karaciğer sirozu hastası dahil edildi. Ortalama yaş $63.1 \pm 13.4$ bulundu. Hastaların 21'i (\%51.2) kadın idi. Hastaların siroz etiyolojileri incelendiğinde 19 hastada kronik hepatit B, 9 hastada kronik hepatit C, 8 hastada etanol, 3 hastada non-alkolik steatohepatit ve 2 hastada kriptojenik nedenler olduğu görüldü.

Hastalara ait demografik özelliklerin (yaş, cinsiyet) vWF düzeyi üzerinde etkili olmadığı görülmüştür. Hastaların, Child-Pugh, MELD ve MELD-Na skorları hesaplandı. Skorlara ait veriler Tablo 1'de sunulmuştur. Son olarak karaciğer hastalığının derecesini gösteren skorlarla serum vWF düzeyleri arasında korelasyon analizleri yapıldı. vWF düzeyinin Child-Pugh, MELD ve MELD-Na skorları ile karşılaştırmasında istatistiksel anlama ulaşan pozitif yönlü bir korelasyon olmadığı görüldü. (Tablo 2). İncelen skorlar ile VWF arasındaki ROC analizi ile elde edilen sonuçlar Şekil 1'de gösterilmiş̧tir.

Yapılan subgrup analizlerde: vWF, bilirubin $2 \mathrm{mg} / \mathrm{dl}$ 'nin altında olan hastalarda medyan 134 absU (86-352), total bilirübin $2 \mathrm{mg} / \mathrm{dl}$ ile $2,9 \mathrm{mg} / \mathrm{dl}$ arasında olan hastalarda medyan 158 absU (96-185) ve total bilirübin 3 mg/dl'ün üzerinde olan hastalarda medyan 225 absU (114-420) olarak hesaplandı. Total bilirübin değeri 2'nin altında ve 3 'ün üzerinde olan grupların medyan vWF değerleri arasında istatistiksel anlamlı farklılı saptandı $(p=0.018)$ (Tablo 3). 


\begin{tabular}{|c|c|}
\hline HES & $(n, \%)$ \\
\hline Yok & $28(\% 68.3)$ \\
\hline Grade $1-2$ & $11(\% 26.8)$ \\
\hline Grade $3-4$ & $2(\% 4.9)$ \\
\hline CHILD (Medyan, Min-Maks) & $8(5-12)$ \\
\hline CHILD & $(n, \%)$ \\
\hline A & $11(\% 26.8)$ \\
\hline B & $17(\% 41.5)$ \\
\hline C & $13(\% 31.7)$ \\
\hline MELD (Ortalama $\pm S S$ ) & $13.9 \pm 4.8$ \\
\hline MELD & $(n, \%)$ \\
\hline Hafif & $13(\% 31.7)$ \\
\hline Orta & $24(\% 58.5)$ \\
\hline Şiddetli & $4(\% 9.8)$ \\
\hline MELD-Na (Ortalama $\pm S S$ ) & $15.7 \pm 6.2$ \\
\hline MELD-Na & $(n, \%)$ \\
\hline Hafif & $13(\% 31.7)$ \\
\hline Orta & $17(\% 41.5)$ \\
\hline Şiddetli (n, \%) & $11(\% 26.8)$ \\
\hline
\end{tabular}

HES: Hepatik ensefalopati, MELD: Model of end stage liver disease, Na: Sodyum

Tablo 2. vWf düzeyi ile diğer değişkenlerin karşılaştırılması

\begin{tabular}{|lcc|}
\hline & $\mathbf{r}$ & $\mathbf{p}$ \\
\hline Yaş & -0.328 & 0.036 \\
\hline Albümin & 0.174 & 0.276 \\
\hline Total bilüribin & 0.278 & 0.078 \\
\hline INR & 0.237 & 0.136 \\
\hline Kreatinin & -0.171 & 0.285 \\
\hline Na & 0.088 & 0.585 \\
\hline PLT & -0.367 & 0.060 \\
\hline CHILD & 0.138 & 0.388 \\
\hline MELD & 0.182 & 0.255 \\
\hline MELD-Na & 0.102 & 0.527 \\
\hline
\end{tabular}

INR: Uluslararası normalleştirilmiş oran, Na: Sodyum, PLT: Platelet, MELD: Model of end stage liver disease

VWF, INR 2.3 altında olan hastalarda medyan 145 absU (86-420) ve INR 2.3'ün üstünde olan hastalarda medyan 312 absU (158-420) olarak hesaplandı. INR 2.3'ten küçük ve büyük olan grupların medyan VWF değerleri arasında istatistiksel anlamlı farklılık saptandı ( $p=0.024)$ (Tablo 3).

Hastaların medyan vWF değeri 176 absU (86-420) ola-
Tablo 3. vWf düzeyinin değişkenlerin subgrupları ile karşılaştırması

\begin{tabular}{|c|c|c|}
\hline & $\begin{array}{c}\text { vWF } \\
\text { (Medyan, Min-Maks) }\end{array}$ & $p$ \\
\hline \multicolumn{3}{|l|}{ Cinsiyet } \\
\hline Kadın & $208(96-420)$ & 0.279 \\
\hline Erkek & 139.5 (86-420) & \\
\hline \multicolumn{3}{|l|}{ Albümin } \\
\hline Normal & $267(86-352)$ & \multirow{3}{*}{0.206} \\
\hline Düşük & 186.5 (99-420) & \\
\hline Çok düşük & $134(96-420)$ & \\
\hline \multicolumn{3}{|l|}{ Total bilirübin } \\
\hline Normal & $134(86-352)$ & \multirow{3}{*}{0.018} \\
\hline Yüksek & $158(96-185)$ & \\
\hline Çok yüksek & $225(114-420)$ & \\
\hline \multicolumn{3}{|l|}{ INR } \\
\hline Normal & $145(86-420)$ & \multirow{2}{*}{0.024} \\
\hline Yüksek & $312(158-420)$ & \\
\hline \multicolumn{3}{|l|}{ Assit } \\
\hline Yok & $267(86-391)$ & \multirow{3}{*}{0.481} \\
\hline Hafif & $143(88-420)$ & \\
\hline Şiddetli & $188(129-352)$ & \\
\hline \multicolumn{3}{|l|}{ HES } \\
\hline Yok & $150.5(86-420)$ & \multirow{3}{*}{0.444} \\
\hline Grade 1-2 & $181(114-420)$ & \\
\hline Grade 3-4 & $220.5(129-312)$ & \\
\hline \multicolumn{3}{|l|}{ CHILD } \\
\hline$A$ & $208(86-335)$ & \multirow{3}{*}{0.247} \\
\hline B & $132(96-420)$ & \\
\hline C & 199 (114-420) & \\
\hline \multicolumn{3}{|l|}{ MELD } \\
\hline Hafif & $158(86-352)$ & \multirow{3}{*}{0.817} \\
\hline Orta & $178.5(96-420)$ & \\
\hline Şiddetli & $171(136-312)$ & \\
\hline \multicolumn{3}{|l|}{ MELD-Na } \\
\hline Hafif & $158(86-352)$ & \multirow{3}{*}{0.449} \\
\hline Orta & $134(96-420)$ & \\
\hline Şiddetli & $199(119-328)$ & \\
\hline
\end{tabular}

VWF: von Willebrand faktör, INR: Uluslararası normalleştirilmiş oran, HES: Hepatik ensefalopati, MELD: Model of end stage liver disease, Na: Sodyum

rak hesaplandı. vWF, 20 (\%48.8) hastada 160 absU ve altındayken, 21 (\%51.2) hastada 160 absU değerinin üstündeydi.

Diğer skorlarla yapılan karşılaştırmada Child-Pugh, MELD ve MELD-Na ile VWF düzeyi $<160$ absU ve $>160$ absU olanlarda anlamlı ilişki saptanmadı. 

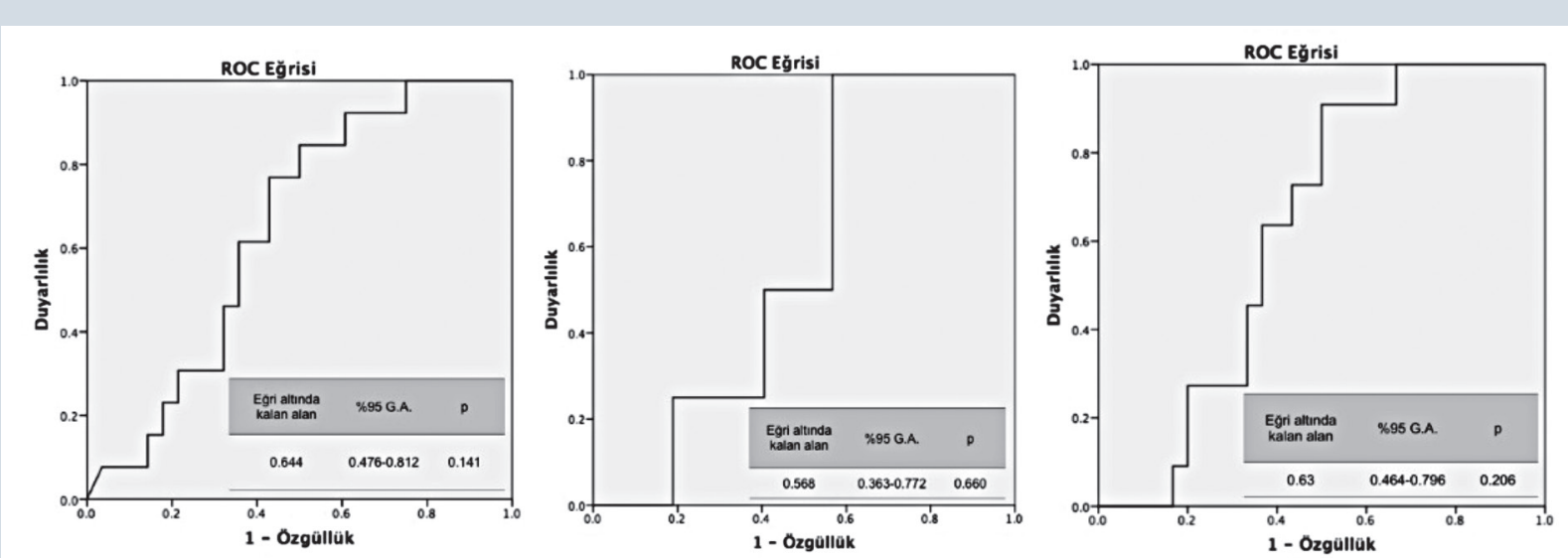

Şekil 1. vWF'nin sırasıya CHILD C, şiddetli MELD ile şiddetli Na-MELD'i predikte etme yeteneğinin araştırılması. Yapılan ROC analizinde eğri altında kalan alan istatistiksel anlamlı olarak bulunamamıştır.

\section{TARTIŞMA}

Karaciğer sirozunda hastalık seyrinin ve oluşabilecek komplikasyonların önceden belirlenmesi, hem etkili tedavilerin verilmesinde hem de transplantasyon gibi prognostik açıdan çok önemli kararların optimal zamanının tespitinde oldukça önemlidir. Bugün için bu amaçla yaygın olarak Child-Pugh ve MELD skorları kullanılmaktadır. Ancak bu prognostik modellerin gerek subjektif kriteler içermesi gerekse kolestatik karaciğer hastalıkları ve asit varlığı gibi klinik koşullarda azalan etkinlikleri dezavantajları olarak görülmektedir (8).

Karaciğer sirozunda portal kan akımına karşı artan direnç portal hipertansiyon patofizyolojisini oluşturur. Hepatik vasküler tonus artmasına bağlı olarak endotel disfonksiyonu olur, ayrıca oluşan endotoksemi nedeni ile vWF düzeyleri artar (7). vWF düzeyinin karaciğer sirozlu hastalarda artmasının bir diğer nedeni de vWF temizlenmesinde görev alan ADAMTS13 proteinaz enzim sentezinin azalmasıdır (9).

VWF ve kronik karaciğer hastalıkları ile ilgili yapılan kontrol çalışmalarda, vWF düzeylerinin sağlıklı gruplara göre karaciğer hastalığı olanlarda daha yüksek olduğu görülmüştür. Ayrıca $v W F^{\prime}$ nin portal hipertansiyonun şiddeti ve kötü prognoz kriterleri ile korelasyon gösterdiği tespit edilmiştir (10).

VWF ve karaciğer hastalıkları ile ilgili yapılan çalışmalarda, vWF serum düzeyleri ile karaciğer fibrozisin derecesi arasında pozitif yönlü anlamlı bir korelasyon görülmüş ayrıca hepatopulmoner sendrom gibi siroz ve portal hipertansiyona bağlı komplikasyonların tanı ve takibinde kullanılabileceği belirtilmiştir $(11,12)$.

Bizim çalışmamızda serum vWF düzeyleri ile karaciğer hastalığının derecesini belirleyen skorlama sistemleri arasında anlamlı ve pozitif yönlü bir ilişki bulunamadı. Ancak subgrup analizlerde total bilirübin ve INR düzeyleri ile serum vWF seviyeleri arasında istatistiksel olarak anlamlı ilişki tespit edilmiştir. Ayrıca çalışmamızda vWF için tespit edilen \%160 absU cutoff değeri baz alındığında skorlama sistemleri ile korelasyon olmaması genel olarak çaışmadaki hasta sayısı ile ilişkilendirilebilir. Diğer taraftan subgrupların randomizasyonunda karaciğer yetmezliği derecelerine göre yapılan gruplandırmada uygun olmayan dağılımların da sonuçlar üzerinde etkili olabileceği düşünülebilir.

Çalışmamızda bazı kısıtıılıklar mevcuttur. Karaciğer hastalığı sürelerine göre subgrup analizlerin yapılmaması sonuçlar üzerinde etkili olmuş olabilir. Ayrıca skorlama sistemleri dışında hastaların kompanse ve dekompanse olarak ayrılarak değerlendirme yapılması daha uygun olabilirdi. Çalışmadaki hasta sayısının daha çok olması da istatistiksel sonuçların daha güçlü olmasını sağlayabilirdi.

Sonuç olarak bu çalışmada serum vWF düzeylerinin karaciğer hastalığı derecesini ön görmede etkili olabileceği yönünde yeterli bilimsel kanıta ulaşılamamıştır. Bu konuda daha yüksek hasta sayıları ile kontrollü çalışmalar yapılması önerilebilir. 


\section{KAYNAKLAR}

1. Lucey MR, Brown KA, Everson GT, et al. Minimal criteria for placement of adults on the liver transplant waiting list: a report of a national conference organized by the American Society of Transplant Physicians and the American Association for the Study of Liver Diseases. Liver Transpl Surg 1997;3:628-37.

2. Everson GT. MELD: the answer or just more questions? Gastroenterology 2003;124:251-4.

3. Cholongitas $E$, Senzolo $M$, Triantos $C$, et al. MELD is not enough-enough of MELD? J Hepatol 2005;42:475-7; author reply 478-9.

4. Londoño MC, Cárdenas A, Guevara M, et al. MELD score and serum sodium in the prediction of survival of patients with cirrhosis awaiting liver transplantation. Gut 2007;56:1283-90.

5. Sadler JE, Budde U, Eikenboom JC, et al; Working Party on von Willebrand Disease Classification. Update on the pathophysiology and classification of von Willebrand disease: a report of the Subcommittee on von Willebrand Factor. J Thromb Haemost 2006;4:2103-14.

6. Gingsburd D. Von Willebrand disease in: Beutler R, ed. Willams Hematology. 6th eds. New York: McGraw Hill 2001;1813-28.

7. Ferro D, Quintarelli C, Lattuada A, et al. High plasma levels of von Willebrand factor as a marker of endothelial perturbation in cirrhosis: relationship to endotoxemia. Hepatology 1996;23:1377-83.
8. Değertekin B. The stage and the prognosis of cirrhosis Türkiye Klinikleri J Gastroenterohepatol-Special Topics 2013;6:22-9.

9. Ferlitsch $M$, Reiberger $T$, Hoke $M$, et al. von Willebrand factor as new noninvasive predictor of portal hypertension, decompensation and mortality in patients with liver cirrhosis. Hepatology 2012;56:1439-47.

10. La Mura V, Reverter JC, Flores-Arroyo A, et al. von Willebrand factor levels predict clinical outcome in patients with cirrhosis and portal hypertension. Gut 2011;60:1133-8.

11. Horvatits T, Drolz A, Roedl K, et al. von Willebrand factor antigen for detection of hepatopulmonary syndrome in patients with cirrhosis. J Hepatol 2014;61:544-9.

12. Maieron A, Salzl P, Peck-Radosavljevic M, et al. von Willebrand factor as a new marker for non-invasive assessment of liver fibrosis and cirrhosis in patients with chronic hepatitis C. Aliment Pharmacol Ther 2014;39:331-8.

13. Yilmaz VT, Dincer $D$, Avci $A B$, Çetinkaya R. Significant association between serum levels of von Willebrand factor (VWF) antigen with stages of cirrhosis. Eurasian J Med 2015;47:21-5. 